\title{
Scioppius' Pen against the English King's Sword: The Political Function of Ambiguity and Anonymity in Early Seventeenth-Century Literature
}

\author{
WINFRIED SCHLEINER
}

\section{$\mathrm{H}$} word-play on "lie," "quick," "man," "woman," etc. until the young prince retreats from the fray by saying to his noble companion (Horatio): "How absolute the knave is! we must speak by the card [i.e., punctiliously], or equivocation will undo us" (V.i.137-38). "Us" here designates princes or at least nobles, as the subsequent reference to courtier versus peasant make clear. Although Shakespeare usually has noblemen win duels of word-play with the lower classes, there is in Hamlet's remark at least a touch of unease about the potential function of ambiguity and double meaning in destabilizing society. In the present essay, while I use the expression 'wordplay' or play on words, I am not focusing on playfulness or innocent fun in twisting words around, what one might consider the activity of homo ludens loquens (to adapt Huizinga's famous term). Rather, encouraged by what has been called 'new historicism' (such as the work of Jonathan Goldberg, Louis Montrose, and Stephen Greenblatt, focusing on the relationship of literature to power and disregarding a presumed division between literary and nonliterary texts), I would like to study the political implications of ambiguity and double meaning, primarily through the work of the person who in the early seventeenth century was feared and hated as the most biting controversialist and satirist of all, Kaspar Schoppe (or Scioppius), one of whose main targets was King James I. But while, as James Holstun has said, most recent North American studies in this field have not been concerned with open resistance to power not with violence and struggle but with subtle forms of subversion that ultimately fail to subvert, ${ }^{1}$ my subject does lead at times to violence: for ambiguity and double meaning as practiced by one of the 
English king's most formidable opponents with the pen led him to violence in murky back alleys and to the kind of unsavory suggestive innuendo that dominate the front pages of tabloids today as much as it did some of the Latin writings of such humanists as Joseph Scaliger, Daniel Heinsius, Isaac Casaubon, and Kaspar Scioppius.

Although Scioppius (1576-1649) was not a subject of King James - he was born in Germany, but after converting to Roman Catholicism, travelled much in Europe, italianized his name, and died in Padua - he experienced James's power even physically, when the English ambassador to Spain had him whipped in a Madrid street. Without privileging any particular dimension (for at issue is also the interplay of religious, social, and national forces), it will be convenient to divide our subject of ambiguity and double meaning into at least two parts: the subject as seen from the viewpoint of the authorities or persons in power, and as seen from the viewpoint of a person reckoning with that power. Therefore let us observe decorum and begin with King James.

James I was probably the most literate king England had ever had: even before he came to the English throne, English writers were aware of his poetic and intellectual interests. The poems and passages that play on his ability to handle both stilum (obliq., the stylus) and pilum (the javelin) are legion. I contend that James would have been interested in my subject in at least three broad senses, of which I borrow the first from Goldberg's James I: and the Politics of Literature, chapter II on "State Secrets": Goldberg reminds us that one of the two mottos King James adopted was Qui nescit dissimulare, nescit regnare. This phrase had been associated with the Emperor Tiberius, reputedly a great dissembler, with whom King James was compared. Goldberg cites such an instance from a letter (1615) of Francis Bacon to the King (in the letter Bacon excuses himself for disturbing the king in his country pleasures). ${ }^{2}$ Then Goldberg adds: "This imperial motto of dissemble rule had poetic consequences; it serves as a paradigm for courtly representation, as Puttenham's discussion of 'the Courtly figure Allegoria' makes clear: in that context, he mentions 'the great Emperour who had it usually in his mouth to say, Qui nescit dissimulare nescit regnare” (Goldberg, p. 69).

Ambiguity and double meaning are politically relevant in predictions and prophecies. In Polimanteia (1606), William Clarke warns against prophecies because they lead people astray by their ambiguity and thus harm the commonwealth. Rolf Soellner has said that at the time of Shakespeare's last plays, England was turning into a nation of prophets. How someone is led along to murder and rebellion by ambiguous promises is dramatized in Macbeth; Sir 
Philip Sidney's Arcadia shows the disastrous consequences for government of listening to a necessarily duplicitous oracle (Arcadia, i.e., the Golden World, is destroyed by it). In fact, almost every English monarch passed laws forbidding political prophecies, laws that were usually repealed by the succeeding ruler, only to be reinstated a few years later. ${ }^{3}$

Double meaning became a highly sensitive political matter in the charged atmosphere after the Gunpowder Plot (1605). At the trial the accused, especially Father Garnet, when shown a contradiction with previous testimony, allegedly defended themselves by saying that they had equivocated. In order not to incriminate themselves, the Jesuit-trained defendants turned equivocation into a rhetorical technique in which they would make a statement or would seem to, but if they framed it carefully enough would - by mental reservation or evasion - withhold assent to its apparent meaning. ${ }^{4}$ In Macbeth the tipsy porter, imagining himself the porter of Hell Gate, says: "Knock, knock! Who's there, in th'other devil's name? Faith, here's an equivocator, that could swear in both scales against either scale, who committed treason enough for God's sake, yet could not equivocate to heaven. O, come in equivocator" (Macbeth, II. iii. 7-11). A little later he adds: "Therefore much drink may be said to be an equivocator with lechery, it makes him, and it mars him ..." (II.iii.30-32). The Gunpowder Plot scared civic and church leaders into something like hysteria, and they did everything in their power to perpetuate that alarm (from then on, sermons on the anniversary of the Plot had to be preached on that subject).

From then on King James also had his subjects swear, along with the Oath of Allegiance, a denial that they were equivocating: "And all these things I doe plainely and sincerely acknowledge and sweare, according to these expresse words by me spoken, and according to the plaine and common sense and understanding of the same words, without any Aequivocation, or mental evasion, or secret reservation whatsoever." Reacting to Roman Catholic polemics, which had compared James to Julian the Apostate and had called the means by which James wanted to enforce uniformity "the devil's craft," James defended the addition in the following way:

For no temperatnesse, nor modification in wordes therein, can justly be called the devils craft: when the thing it selfe is so plaine, and so plainely interpreted to all of them that take it: as the onely troublesome thing in it all, be the wordes used in the end thereof; for eschewing aequivocation and mental reservation. Which new, Catholique doctrine, may far iustlier be called the devils craft, than any plaine and temperate words, in so plaine and cleare a matter. But what shall we say of these strange contrey clownes, 
whom of with the Satyre we may iustley complaine, that they blow both hote and cold out of one mouth (Triplici nodo, pp. 61-62)

Thus "equivocation" became a notion so heavily charged that (using a term developed by Frederic Jameson) we may call it an "ideologeme," the smallest unit of an ideology. 6 The attitude towards equivocation of writers aligning themselves with authority is always negative or derogatory, and it is not surprising that in his well-known essay "Of Simulation and Dissimulation," in which he even approved of the use of ordinarily culpable simulation "in great and rare matters,"7 Francis Bacon rejects equivocation.

The subject of equivocation forms a convenient link with the other half of my subject, namely the use of ambiguity and double meaning by those not in power, by those up against authority of whatever sort. The very purpose of equivocation, as it became the focus of attention at this historical moment in the seventeenth century, is of course defense against authorities whose legitimacy was questioned. So far I have outlined only official reaction to this rhetorical and moral strategy.

One of those who for many years opposed the authority of King James was Kaspar Scioppius, who in 1611 published a book of 566 pages entitled Ecclesiasticus auctoritati Serinissimi D. Iacobi Magnae Britanniae Regis oppositus. As the place of publication, the title page give "Hartberga," which would be modern Harburg near Hamburg. However, there was no press in Harburg at that time, and we may trust the detective work of an enemy of Scioppius's, writing under a pseudonym, who identifies the place of publication as Meitingen near Augsburg. ${ }^{8}$ That Scioppius is eminently conscious of a difference of rank between himself and his royal opponent - and somewhat cautious - is also dedicated by his revelation that he has been admonished to deal with the king without hardness of words (acerbitas verborum); but he admits that "it is difficult to deal with the enemy of one's religion without reviling him (maledicere, p. 68, margin). He perceives that his religious antagonism may have got the better of his civil and civic decorum.

Of all the arguments in this big book I am interested at present in only.one that Scioppius was to use again and again in his publications against King James. Adopting a pose that I think is more than mere tierischer Ernst (gross, humorless seriousness) of a German grammaticaster and indecorous polemicist, being rather that of the satiric revolutionary, Scioppius sets himself up in the manner of King James himself as an authority that will brook no word play. Of course he knows and refers to King James's distrust of the Jesuits for their alleged tendency to equivocate (Ecclesiasticus, p. 99). ${ }^{9}$ 
To appreciate the argument now to be summarized, we must remember that ever since his accession to the throne James had been attracted to the notion of becoming the unifier and head of all protestant factions that were opposed to Rome. Over the years, various political/diplomatic enterprises were undertaken to that end. One of James's best-known diplomats was Sir Henry Wotton, who in 1604 travelled through Europe to become the English ambassador in Venice. While stopping in Augsburg, Wotton committed an indiscretion that Scioppius would never let him forget. In the album of a friend, in which according to German habit (ad consuetudinem Germanorum) one entered one's name and some memorable phrase, he wrote a witty definition of an ambassador, signed it, and with great pomp added his official title: Henricus Wotonius, Serenissimi Angliae, Scotiae, Franciae \& Hiberniae Regis Orator primus ad Venetos (then follows place and date). Wotton's definition was, "An ambassador is an honest man sent to lie abroad for the good of his country." One meaning of 'to lie abroad' in Wotton's sentence is of course 'to dwell abroad'. Unfortunately it seems that Wotton was thinking in English and writing in Latin. As Isaac Walton, Henry Wotton's contemporary and first biographer, puts it: "The word for lye (being the hinge upon which the Conceit was to turn) was not so exprest in Latine, as would admit (in the hands of an Enemy especially) so fair a construction as Sir Henry thought in English." 10 According to Scioppius, Wotton wrote: "Legatus est Vir bonus, peregre missus ad mentiendum Reipub. causa." ${ }^{11}$ Scioppius claims that the Augsburg citizens regarded the diplomat's self-revelation with astonishment. Here was a king who sends out diplomats to cities to have them spread lies. By his revelation Wotton added stupidity to malice, Scioppius comments, citing Proverbs 10:23: "Quasi per risum, stultus aperatur scelus" (It is a sport to a fool to do mischief).

If Wotton wrote the definition in Latin, we cannot determine for certain whether Scioppius could see the English pun that no doubt was on Wotton's mind. That he adduces the Proverb (with the phrase "quasi per risum") would suggest that he perceived something jocular, playful, or pointedly clever in the definition - although the submerged English homonymic pun on 'lie' is not the only possibility.

In continuing his polemics against the king who detested equivocation, Scioppius would harp on this incident, the presumed self-revelation of the English legatus. He does so the same year in a polemical piece directed primarily against the great humanist scholar Joseph Scaliger. ${ }^{12}$ In the course of describing what he alleges is the nefarious technique of the Calvinists, of forging letters in order to harm their supposed authors, Scioppius again refers to the moral turpitude of the "Calvinist" ambassador (i.e., Wotton) who took 


\section{6 / Renaissance and Reformation}

pride in the fact that he was sent to lie rei publicae causa, i.e., for Calvinism. The definition is quoted again: Legatus est vir bonus, peregre missus ad mentiendum reipublicae causa (p. 294). Apparently Wotton's gaffe became well known in Europe. Isaac Walton reports that "in Venice [the definition] was presently after written in the several Glass-windows, and spitefully declared to be Sir Henry Wottons" (p.121).

When King James read Scioppius' account of his ambassador's comportment, he was not pleased. According to Logan P. Smith, Wotton's modern biographer, James was so angry that he brought the matter up at dinner and demanded an explanation from Wotton in front of the entire court (Smith, Vol. I, p. 127). We do not know whether Wotton talked about ambiguity and double meaning (which would not have sat well with a king whose views on equivocation were well known), except that he tried to pass the matter off as a joke. King James could have quoted to him Hamlet's words about speaking "by the card, or equivocation will undo us." But it was no laughing matter to the king, who demanded that Wotton clear himself (Smith, I, p. 127). As a result Wotton wrote two apologies, a letter to the king (which has disappeared) and another to his friend Marc Welser, an Augsburg patrician.

Smith is imprecise on the dating of this letter, assuming that it was published in 1612 and 1613; apparently he had not seen the original publication (he says, "as far as I know, no copy of the original publication has been preserved," Vol. II, 9n.). Wotton in fact dated it Dec. 17, 1612, and it was published in 1613 at Grafenhainichen (Haga Comes), where King James's Apologia had also been printed. ${ }^{13}$

I am less interested here in Wotton's attack on Scioppius, whom he calls a semidoctus grammaticaster, than in his explanation of the definition. He says, "I do not know how I came upon that 'unserious definition" (definitio iocosa), but then he calls it "to a point perhaps universal" (adeo fortasse catholica) since legatus can be understood as a latere (i.e., from the side, sideways), another quite meaningful pun, or one may call it false etymology. He complains that in his malice Scioppius applies only the most elementary reading (elementissima interpretatio) to something that he, Wotton, had written not only unseriously but lightly (iactanter). He also talks about the genre of album amicorum, in which true and false are equally and safely at home. Most interestingly, he tries to distance his use of double meaning from that of the equivocators so detested by the king. For he wonders why so much political hay is being made out of a short joke at a time when "we see that even the earnestness of sacrosanct theology has been so foully besmirched by certain master of aequivocations, mental reservations, and pious frauds." 
Scioppius' reply appeared in 1614 in a work that squeezes more meaning out of the word legatus, entitled Legatus latro, Hoc est: Definitio legati Calviniani (Ingolstadt, 1614). Scioppius reports the Augsburg incident again in full detail and then replies to the published letter. Here, he scoffs, is a legatus who in a letter, apparently published with royal authority, claims that he has not lied in his definition of the legatus as lying. And he quotes Wotton's defense that the definition is to some extent universal (catholica) since legatus can be understood a latere. For good measure he adds another anecdote revolving around a pun or jingle. When Sir Henry Wotton was ambassador in Venice, he supposedly came upon another diplomat who said : Io vado a complire (I am going to succeed - i.e., accomplish something). According to Scioppius, Wotton then "openly and simply revealed himself by saying: Et io vado a mentire, i.e., I am going to lie because of my office "(p.2). Although Sir Henry Wotton's Italian was so good that he easily could have made this retort (in fact his knowledge of Italian was so good that in his first secret mission he was able to pass for an Italian), I cannot tell whether this report is true or invented. Of course this anecdote follows the pattern of the first and historical one: the emissary of the hated authority is shown to reveal his duplicity by a witty jingle. Whether invented or dredged up by concerted muckraking (for which Scioppius had a reputation), the pun here and elsewhere is effective ammunition for the controversialist, for whom the stilus or pen was the only weapon since he did not have the use of the pilum or javelin, the symbol of royal power. ${ }^{14}$

In the rest of the work Scioppius tells a rather exciting tale of how he became a victim of that power. He reports how the sycophants and literary mercenaries (latro originally meant mercenary) of supposedly "the best, wisest, and most learned king" (p. 12) have tried to ruin his reputation by slandering his parents, i.e., questioning his descent. (Incidentally, Scioppius himself may deserve the dubious honor of being the absolute master of that technique.) He quotes a long list of the most reprehensible names that he has been called: "infamis nebulo; pestis; canis impurus; filius Belial; homo non suae spontis, sed certissime insanus; scelestus; genimen viperarum; foetor orbis; Styx et mendaciorum cloaca; vilis homuncio; bibedum postremissimus; maledicentissimus homo, cuius iuventus per flagitia transacta; Thersites; prostituti pudoris nebulo; sycophanta".

If the catalog were an invention of Scioppius the rhetorician, one would say ben trovato; however, such appellations can actually be found in the acerbic comments of Scioppius' enemies, notably Isaac Casaubon, Joseph Scaliger, and Daniel Heinsius. Scioppius skillfully arranges the catalog to 
form a climax, for the final berating words cited are: "spurcus nebulo, qui medicina opus habet, sed violenta, cuius morbus non verbis aut incantatione, sed ferro aut sectione curari debet" (Legatus latro, pp. 14-15).

He tells of emissaries sent to the Augsburg authorities to put pressure on him and prevent his words' publication (p. 16), and of an attempt in Rome to shoot him through a window as he was reading a book (p. 18). Since he suspects that English authorities are behind these attempts, he now and again cites a variation of Sir Henry Wotton's notorious definition of legatus, which becomes a polemically effective refrain:

Legatus Calvinianus sit vir bonus peregre missus ad mentiendum \& latrocinandum suae Reipub. causa.

As he does in the title Legatus latro, Scioppius is here playing not only on Wotton's definition but also on his explanation legatus a latere. Latro, originally the "hired servant" or "mercenary," usually means "bandit" or "gangster", and latrocinare is to act like one. Shaped by his sharp pen, legatus for an English or "Calvinist" ambassador is passed off as a would-be or pseudo-ideologeme denoting the emissary of a duplicitous nefarious power.

As a final kicker and proof for the emended definition, he reports an incident that happened to him at Madrid. In the middle of the night he was warned of impending danger because of the "deadly hat of the English ambassador" (de capitali odio Legati Anglicani, p. 28), and shortly afterwards, March 21, 1614, was indeed waylaid by a couple of men hired by the English ambassador, Sir George Digby. They beat him and, as Scioppius put it, he escaped with no worse than a minor wound in his side, only because a pad of paper warded off the knife. "Because of the work of this ambassador, no one can have any doubt that the Wottonian definition of the legatus can now be rightly completed:

Legatus Calvinianus, maxime Anglicanus, est vir bonus; peregre missus ad mentiendum et latrocinandum Reipub. suae causa (p. 44).

Like many of Scioppius' works Legatus latro was published under a pseudonym although it is quite clear from the many reference to Scioppius' life that he or someone very close to him is the author. With the publication, he took the risk not only of angering English authorities further but also of publicizing his beating. One should not underestimate the tendency of most citizens, including the literati, in those authoritarian times to identify with royal authority, even a foreign one. The sub-text in most older encyclopedias 
I checked on the subject is essentially that for challenging the English king Scioppius deserved what he got. One view from the middle of the eighteenth century and another from the middle of the nineteenth may stand for others.

Es ist kein Zweifel, dass Scioppius . . . die Erzählung dieser Sache, die sich den 21sten März 1614 zutrug, nicht solte vergrössert haben. Die ganze Sache endigte sich vermuthlich mit einigen Streichen, die das geringste waren, da $\beta$ [sic] er verdiente; denn es scheint, da $\beta$ er sich nicht viel daran gekehret habe. ${ }^{15}$

Or by another account:

Il se mit aussi à bafouer Jacques $I^{\mathrm{er}}$, roi d'Angleterre, dans plusieurs libelles, qui sont peut-être les plus satiriques et les plus venimeux qui existent dans aucune langue; aussi ne se plaignit-on pas trop, lorsque, se trouvant en 1614 à Madrid, il fut bâtonné par les gens de lord Digby, ambassadeur d'Angleterre. ${ }^{16}$

We note, incidentally, that this French writer develops his point with rhetorical skill: for bafouer the English king, Scioppius was bâtonné; the jingle expresses the point that the beating was a mere tit-for-tat.

How then could a literatus challenging royal authority avoid the kind of treatment Scioppius suffered and for which there was apparently no redress? By increasing both ambiguity and double meaning. He could raise the level of ambiguity by not inscribing his name into the work; he could craft it in such a way that every part, introductory frame, and main discourse was parody and thus had double meaning. Scioppius did this in Isaaci Casauboni Corona Regia. Here he left out his name entirely. The title page proclaims this to be the work of the great classicist and Protestant theologian Isaac Casaubon (whom King James had called to England to defend the Anglican Church). The title page also says (falsely) that this work was published in London by the royal printer John Bill (1615). The book pretends to be Casaubon's praise for King James, i.e., it is mock panegyric or satiric praise. Scioppius fathered it upon Casaubon because he (whom Scioppius called one of James's mercenaries) had written elaborate praises of the wise and devout King James, e.g., to Philippe Mornay Du Plessis - such letters were then usually published to promote James' pretensions to becoming the unifier of all European Protestants. Now Isaac Casaubon had just died in 1614; so Scioppius added another fiction: that the work consisted of fragments of an unfinished work by Casaubon and that these fragments were put together by someone calling himself Euphormio. This had the additional benefit of explaining why the 
piece was perhaps a little ragged. Indeed, Scioppius now and then inserts ellipses to indicate that some fragments are missing. The mock praise was so stinging that a reward was offered for the discovery of the author, which was claimed (as Mark Pattison reports) as late as 1639 by a Brussels bookseller. ${ }^{17}$

The work appears to have three prongs of attack. 1. With the name "Euphormio" Scioppius possibly wanted to lampoon the writer John Barclay, who in a religious satire entitled Euphormionis Lusinini Satyricon, a satire of which the first part was much liked by King James since it praised him, had represented himself by that name. Like Casaubon, Barclay (who was later to write his famous roman à clé "Argenis") had come to London to attend upon the king. Phormio, incidentally, appears in comedies by Terence as a garrulous parasite, but $E$ uphormio would represent a good parasite. ${ }^{18} 2$. Corona Regia was supposed to show the alleged hollowness of Casaubon's character, since for the king's gold he praised what was not only non-praiseworthy but reprehensible. 3. It was intended to assail the character of King James. In fact, in the mid-eighteenth century it was still (as we have seen) called the most stinging satire ever directed against a prince. ${ }^{19}$

To cite some examples of this damning praise, Scioppius has Casaubon congratulate James for clandestine nights of voluptuousness with members of both sexes: "for what in these cold climes is wonderful and rare, in you is manly and royal" (p. 68). He talks at length about the young male favourites that James sought out and showered with the highest honors, such as the handsome Robert Carr: "I would praise the fortune of the young man, if your humanity (humanitas) has not outdone me" (p. 92). Then Scioppius recounts how the young man was made Viscount of Rochester, then Earl of Somerset, then "Magnus Cubicularius tuus" (your Knight of the Bedchamber - in this context an ambiguous title). Finally, when the favourite had matured, the king added to these gifts a wife, "obtained by an extraordinary divorce" (this refers of course to the notorious divorce of the Earl of Essex from Lady Frances Howard, in which indeed James personally argued for the divorce, because of, as he put it, maleficium versus hanc, i.e., a selective impotence caused by the devil). Next was a youth of incomparabilis forma, Georges Villiers, "introduced by the queen herself into your chamber, where he was the same day made both knight and a Cubiculo and soon received from the royal treasury a pension of 10,000 florins per year" (p. 92). Scioppius has Casaubon, the world-renowned classicist turned theologian, say unctuously to the king: “Christ's word was 'Sinite parvulos venire ad me.' You call the boys, particularly handsome ones, to you and appreciate in them the gifts and wonders of nature" (p. 105). Referring of course to James' published works 
as a poet, scholar, and theologian, he acknowledges with damning praise: "You demonstrate with admirable wisdom and a sanctity unheard of until now that Venus can be mixed with Minerva, lust with religion" (104-05). Like a true parasitical court poet, he is at a loss for comparisons and asks whether he should associate James' famous name with Heliogabalus (p. 100), who (as Scioppius' readers would know) delighted so much in tabooed sexual pleasures that his name was post factum scratched from the list of Roman emperors. "If you were handsome and had a similarity to the peacock," Scioppius continues, "I would refer to your tail" (p. 102) - in the context of sexual innuendo of course so ambiguous as to become almost unambiguous.

In this satiric parody, in many ways the non plus ultra of satire directed against authority, we see double meaning worked out with a skill that is admirable and occasionally still pleasurable, but also with a relentlessness that approaches the pathological. The adopted form of speaking through someone else (Casaubon) is intimately linked with the underdog's need to remain anonymous. This ambiguity remains defensive, as was the recusants' equivocation. But then this defensive ambiguity of anonymity here becomes the condition and vehicle for the most stinging aggression a literatus can be capable of. At the same time, this pretended letter written be Casaubon to the king is of course not a fraud of the kind which Scioppius himself singled out as nefarious because it is not forged: almost immediately, through unmistakable signals of irony, it is recognizable as fiction, as literary parody, a work of art. The relentlessness of the underdog is more understandable if we remember that this underdog, whom contemporaries called canis grammaticus (the watchdog of Latin grammar) had been beaten. This reading would go a long way toward explaining the paradox observed by a Frenchman at the end of the seventeenth century that in the "famous Scioppius" we have the unusual example of someone not "humanized by the humanities" but made more "farouche". ${ }^{20}$

Much has been written about the rhetorical and necessarily classical schooling of the age, and it would be foolish to belittle the importance of educational systems in which even schoolboys were made to classify and imitate rhetorical modes. Yet such explanations leave us with the apparent contradiction that according to such a large and reliable survey as E. R. Curtius's European Literature and the Latin Middle Ages, the demise of school rhetoric (in belles lettres, politics and pulpit oratory) does not occur until the Romantic period while word-play is already decried by Samuel Johnson and his contemporaries as a manifestations of "false wit". Of course there are other threads, such as the emergence of what came to be perceived 
as a new philosophical and scientific style, that would have to be woven into a more complex representation of the history of literary taste. The case of Scioppius, a man as well known then as he is forgotten now (because he wrote in the "universal language"), may show in cameo the influence of power on one individual's use of language. That this poligrafo finally died amidst unpublished manuscripts in a small room where he had lived in poverty and fear of persecution may mean that he suffered what we now call paranoia. But being paranoid does not prove that one is not being followed. His changing attitude towards ambiguity may have paradigmatic importance.

While in his early work Ecclesiasticus Scioppius had assumed as it were an authoritarian pose in attacking a king through his legate's word-play (a pose that for his contemporaries apparently smacked of hubris), but by contrast after his cudgelling he increasingly adopted the pose of the "knave" (to take Hamlet's word for the punning gravedigger) in his uses of ambiguity and double meaning. In Legatus latro he not only outdoes Sir Henry Wotton (who in an aristocratic fashion had merely toyed with double meaning, showing his wit and sometimes his lack of it), but makes word-play into something entirely different from a pleasing and inconsequential game: a weapon of the weak against the powerful. In Corona Regia he has finally sharpened his tools into moral weapons, although parodic subversion of literary forms of public praise (of which the break with prevailing decorum forbidding mention of the king's homoeroticism is but one element) is accomplished at considerable cost. Thirteen years earlier, in one of his earliest controversies (against Aegidius Hunius, 1601), he had proudly proclaimed in his epistola dedicatoria: "I am German, that is, of that nation which among almost all nations has made the praise of candor, truth, and free speech something like its own: this I will remain as long as I have spirit." ${ }^{21}$ In Corona Regia any sense of self-esteem, whether national or social, has been jettisoned. Effective concealment of his authorship demonstrates his stance to be that of the knave, quite different from the one adopted earlier when he expressed his daring by trading arguments with a king. While this subversion thus is self-destructive, eroding the foundations of public discourse, it of course does not lead to acceptance: it succeeds in questioning the opposing power's officially promoted image and legitimation. From this perspective the words of the Danish prince seem prophetic of the Jacobean stance on ambiguity: "How absolute the knave is! we must speak by the card, or equivocation will undo us." 


\section{Notes}

1 See James Holstun's paper on the Ranters, "Ranting at new Historicism," Conference for Seventeenth-Century Studies, Durham, July 1987.

2 Jonathan Goldberg, James I and the Politics of Literature (Baltimore and London: Johns Hopkins University Press, 1983), p. 68.

3 Rolf Soellner, Timon of Athens: Shakespeare's Pessimistic Tragedy (Columbus: Ohio State University Press, 1979), p.80. On prophecies, see also Henry Howard, Defensative Against the Poyson of Supposed Prophecies (London, 1584); Keith Thomas, Religion and the Decline of Magic (New York: Scribner, 1971), especially chapters 11 \& 13; and Rupert Taylor, The Political Prophecy in England (New York: Columbia University Press, 1911), pp. 104-05.

4 On equivocation and related topics, see Frank L. Huntley, "Macbeth and the Background of Jesuitical Equivocation," PMLA, 97 (1964), 390-400; Steven Mullaney, "Lying like Truth: Riddle, Representation and Treason in Renaissance England," ELH, 47 (1980), 32-47; Robert Weimann's chapter "Das närrisch-realistische Wortspiel," in his Shakespeare und die Tradition des Volkstheaters (Berlin: Henschel, 1975), 215-46; and ch. 6 ("Internal Debate - 'Casuistry") in Elliot Rose, Cases of Conscience: Alternatives Open to Recusants and Puritans Under Elizabeth I and James I (Cambridge University Press, 1975).

5 James I, Triplici nodo, triplex cuneus, or Apologie for the Oath of Allegiance (London, 1609).

6 Frederic Jameson defined this term (conceived in analogy to a morpheme) in The Political Unconscious (Ithaca, N.Y.: Cornell University Press, 1981). See particularly p. 115 and pp. 220-222.

7 Bacon, Works, ed. J. Spedding et al. (London, 1861), vol. 6, p. 389.

8 See Eugenius Lavanda (i.e., Melchior Inchofer), Grammticus palaephatius sive nuvigendus Hoc est, In tres Consultationes Gasparis Scioppii De ratione studiorum scholia et notationes (n.p., 1639), p. 38.

9 Although Scioppius is in this case squarely on the side of the English recusants, we know from some of his other publications that he was not a friend of the Jesuits (under the pseudonym Alphonso de Vargas he published what may be the most biting diatribe ever written against that order). See Alphonso de Vargas (i.e., Schoppe), Relatio ad Reges et Principes Christianos de Stratagematis et Sophismatis Politicis Societatis Iesu (n.p., 1636); and a German edition, Erzählung der Räncke, Betrügereien und politischen Griffe der Jesuiten (Güstrow, 1675).

10 Izaak Walton, The Lives of John Donne, Sir Henry Wotton, Richard Hooker, George Herbert and Robert Sanderson (Oxford University Press, 1927), p. 121.

11 Scioppius, Ecclesiasticus, p. 13. The incident is discussed by Logan Pearsall Smith in The Life and Letter of Sir Henry Wotton (Oxford: Clarendon Press, 1907), I, p. 49 \& p. 126.

12 [K. Schoppe], Operini Grubinii Amphotides Scioppiniae. Hoc est responsio ad Satyram Menippaeam Josephi Burdonis Pseudo Scaligeri (Paris, 1611).

13 The Herzog August Bibliothek, Wolfenbüttel, has a copy. 
14 On stilum: pilum and sceptrum: plectrum, see Scioppius, Sciorpiacum (Mainz, 1612), p. 14.

15 Johan Peter Niceron, Nachrichten von den Begebenheiten und Schriften berümter Gelehrten (Halle, 1759), 19. Teil, p. 308.

16 Nouvelle biographie générale (Paris, 1864), "Schopp" entry.

17 See Mark Pattison, Isaac Casaubon (2nd ed.; Oxford: Clarendon Press, 1892), p. 482; and Calendar of Clar. State Papers, I, 195.

18 See John Barclay, Euphormionis Lusinini Satyricon, ed. David A. Fleming, Bibliotheca Humanistica \& Reformatorica, VI (Nieuwkoop: De Graaf, 1973). On Euphormio, see pp. 336-37.

19 Niceron, Nachrichten, 19. Teil, p. 309.

20 Adrien Baillet, Des enfans devenus célèbres par leurs études ou par leurs écrits (Paris, 1688), p. 245: "Une belle description que l'on feroit de la Vie du fameux Gaspar Scioppius, seroit peut-être la peinture la plus bizarre que l'on pust faire d'un scavant Barbare que la Science auroit rendu plus fier et plus farouche que la Nature ne l'auroit produit en naissant. Il faut avouer que les Humanitez et Belles Lettres qui ont coutûme de former et de polir les Esprits bien nez avoient eu peu de vertu pour civiliser ou seulement humaniser le sien." At this chronological distance terms like humanités, belles lettres, and polir bespeak their ideological charge particularly clearly. It is also worth noting that Baillet includes Scioppius as one of only two German savants in his book. The other one is Gaspar Barthius who gained his reputation by writing a book of epigrams against Scioppius.

21 Scioppius, Apologeticus adversus Aegidium Hunium (Munich, 1601), Sig. 2v: "Ego Germanus sum, hoc est, ex ea natione, quae candoris, sinceritatis et in loquendo libertatis apud pleraque omnes nationes quasi propriam fecit: et is manebo, quamdiu mihi spiritus." 